\title{
Responses of fish to experimental introduction of Structural Woody Habitat in riffles and pools
}

\author{
Timothy D. Howell ${ }^{1,2}$, Angela H. Arthington ${ }^{1}$, Bradley J. Pusey ${ }^{1}$, Andrew P. Brooks ${ }^{1}$, \\ Bob Creese ${ }^{2}$, Janet Chaseling ${ }^{1}$. \\ ${ }^{1}$ Australian Rivers Institute, Griffith University, Nathan, Queensland 4111, Australia. \\ ${ }^{2}$ New South Wales Department of Primary Industries, Port Stephens, New South Wales, Australia.
}

\begin{abstract}
The declining condition of river systems associated with rapid development of human societies has led to substantial declines in fish diversity. One cause of decline is the loss of in-stream Structural Woody Habitat (SWH), an important component of stream ecosystems, particularly as fish habitat. As a result there has been an increase in the number of rehabilitation programs that introduce SWH into rivers. This paper assesses fish responses to SWH introduction in riffles and pools in the Hunter River, eastern Australia, using a Multiple-Before-After-Control-Impact (MBACI) experimental and analytical design. In the riffle experiment, species richness was comparable among all control and treatment riffles across the entire study period. However, there were significant differences in assemblage structure, fish abundance and biomass between control and treated riffles. The introduction of SWH (bank embedded deflector jams) appeared to create additional habitat which was utilised by one native fish species (Retropinna semoni - Australian smelt) and one alien species (Gambusia holbrooki - mosquito fish). In pools there were no significant changes in fish species richness, abundance or biomass following introduction of SWH (pool jams). These findings have important practical and cost implications in terms of the design and implementation of rehabilitation strategies using $\mathrm{SWH}$ to restore fish assemblages in degraded streams.
\end{abstract}

Key words; Hunter River, large woody debris, MBACI experimental design, New South Wales, Australia, pool - riffle habitat, river restoration.

\section{Introduction}

Throughout Australia and much of the developed world there has been a concerted effort to mitigate the excessive pressure being placed upon river systems and restore their ecological integrity. Stream rehabilitation works are typically costly and are becoming increasingly common (Bernhardt et al. 2005; Palmer et al. 2005). One of a wide range of techniques used to rehabilitate rivers for fish is the restoration of instream habitat structure (Pretty et al. 2003; Roni et al. 2005). Many of these works are seen as an end in themselves (Race 1985) and few are evaluated to determine their success or failure with respect to improvement of habitat for fish (Chapman 1999; Lake 2001). Of the works that are evaluated there is often little consideration given to the experimental design required to permit a rigorous scientific and statistical assessment of ecological outcomes (Chapman 1999; Downes et al. 2002; Roni et al. 2005). Consequently, these evaluations contribute little to our capacity to employ rehabilitation measures effectively (Minns et al. 1996; Michener 1997; Smokorowski 
et al. 1998). To direct effective rehabilitation works in the future, there is a need for a better understanding of the types and scales of ecological responses that can be expected from habitat restoration (Lake 2001; Palmer et al. 2005). This can only be achieved through quantitative assessment using appropriate experimental designs and statistical analyses (Palmer \& Filoso 2009).

This paper examines fish responses (changes in fish assemblage composition, species richness, abundance and biomass) to the introduction of Structural Woody Habitat (SWH) (large woody debris), in the Hunter River, a regulated system on the central coast of New South Wales, eastern Australia. The experimental introduction of SWH in riffles and pools was part of the Upper Hunter River Rehabilitation Initiative (UHRRI), a research program designed to examine ecosystem responses to river rehabilitation involving riparian vegetation replanting and fish habitat manipulation (Brierley et al. 2005; Brooks \& Cohen 2005). We examined fish responses in riffles and pools treated with two different types of $\mathrm{SWH}$, each designed to increase habitat diversity in reaches which lacked SWH (riffles) or had low SWH (pools) before treatment. Differences in fish species richness, abundance and biomass in control and treated riffles and pools were quantified using a MBACI experimental design (Downes et al. 2002). Implications for practical rehabilitation of this degraded lowland river are discussed.

\section{Methods}

\section{Study sites}

The UHRRI rehabilitation study area was situated $5 \mathrm{~km}$ south-west of the town of Muswellbrook within a $10 \mathrm{~km}$ reach of the Hunter River classified as a meandering gravel bed stream (Fig. 1) (Spencer et al. 2004). The reach is approximately $200 \mathrm{~km}$ from the river mouth at an altitude of about $130 \mathrm{~m}$ above sea level with an upstream catchment area of $4,220 \mathrm{~km}^{2}$ (Brierley et al. 2005). The reach is located on a floodplain and has been extensively modified since European settlement by landuse changes, river 'training', water resource development, and alien flora and fauna (Howell 2008). Flows through the study reach are largely regulated by Glenbawn Dam $44 \mathrm{~km}$ upstream from the study site. However, large unregulated flows originating from tributaries of the Hunter River entering below Glenbawn Dam periodically occur through the reach, although no such flows occurred during the study period.

The fish component of the UHRRI program involved the addition of SWH to riffles and pools along the study reach (Fig. 1). Six study riffles were located within the UHRRI reach (Riffles 1-6). Riffles 1, 2 and 4 were randomly selected for treatment and Riffles 3, 5 and 6 were used as controls. Distances between the riffles in the UHRRI reach ranged from 55 to $510 \mathrm{~m}$. Due to the relative proximity of the UHRRI reach riffles to each other, two additional control riffles were identified, one $6.5 \mathrm{~km}$ upstream, at the top of the UHRRI reach (Key's Riffle), and one $6.5 \mathrm{~km}$ downstream external to the UHRRI reach (Olive Riffle) (Fig. 1). These riffles were considered likely to be spatially independent of the six riffles within the Hunter study reach. This assertion is supported by a concurrent tagging study in which recaptured specimens of Cyprinus carpio (common carp), Macquaria novemaculeata (Australian bass) and Mugil cephalus (sea mullet) displayed exceptionally strong site fidelity, with only a 
single specimen of $M$. cephalus recaptured at a distance of more than $1 \mathrm{~km}$ away from the tagging site after periods of up to 16 months (Howell 2008).

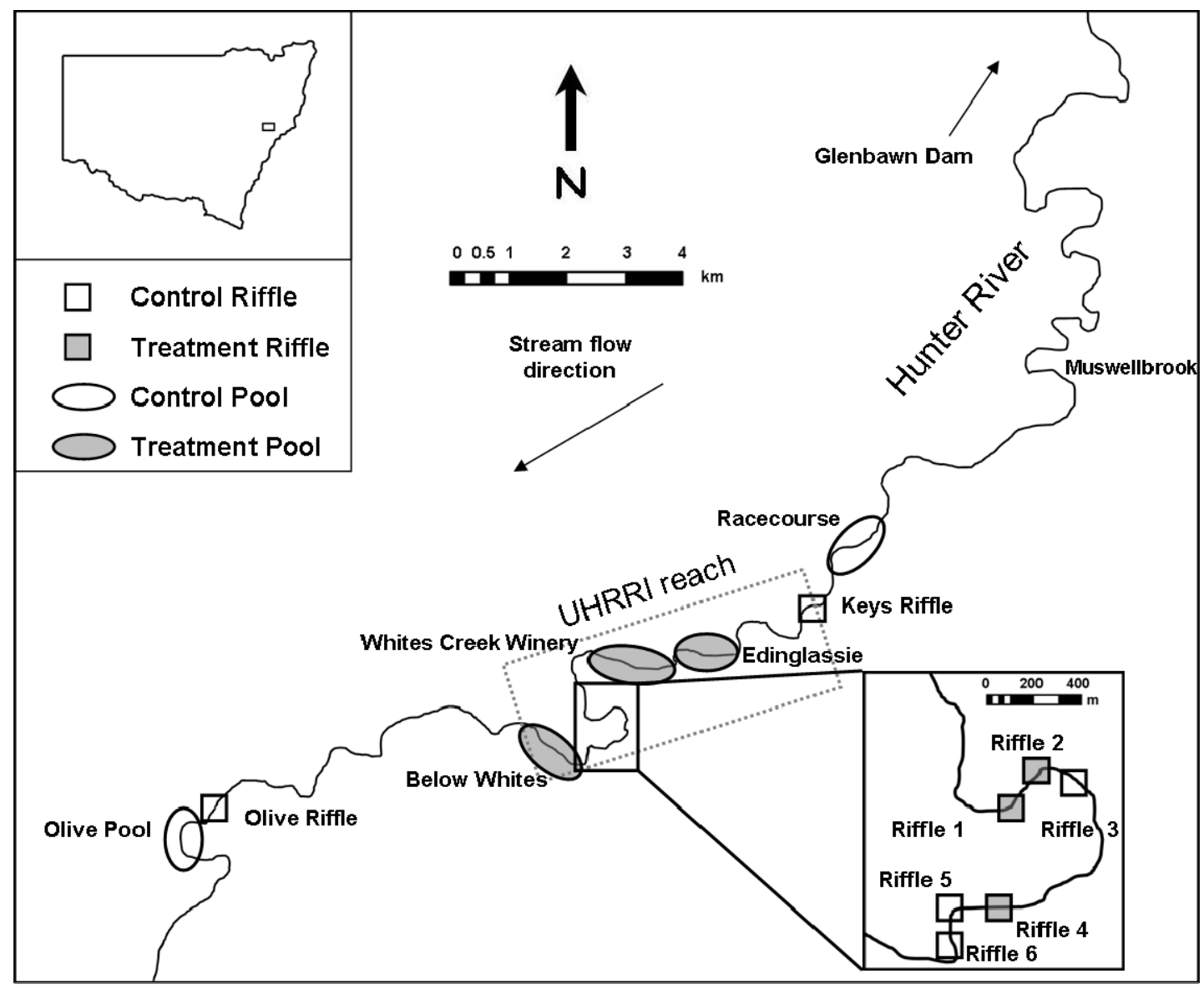

Figure 1. Map of the Hunter River showing the location of riffle and pool sites. All habitat manipulations were carried out in the Upper Hunter River Rehabilitation Initiative (UHRRI) reach.

Three pools within the UHRRI reach were selected for reintroduction of SWH on the basis of comparable morphological and riparian characteristics. Pools were located at Edinglassie, Whites Winery, and a location called Below Whites (Fig. 1). Two comparable control pools (Racecourse and Olive pools, Fig. 1) were chosen at sufficient distances from the UHRRI pools (3.9 km upstream of Edinglassie pool and $5.1 \mathrm{~km}$ downstream of Below Whites pool) to be considered spatially independent. The physical dimensions of all the study sites are provided in Table 1. 
Table 1. Physical habitat variables (mean \pm SE) measured at each riffle and pool study site in the Hunter River during fish surveys under base flow conditions. All velocity measurements have flow exceedence probabilities greater than $99 \%$.

\begin{tabular}{|c|c|c|c|c|c|}
\hline Site name & $\begin{array}{l}\text { Length } \\
\text { (m) }\end{array}$ & $\begin{array}{c}\text { Area } \\
\left(\mathrm{m}^{2}\right)\end{array}$ & $\begin{array}{c}\text { Mean Width } \\
(m)\end{array}$ & $\begin{array}{c}\text { Mean Depth } \\
(m)\end{array}$ & $\begin{array}{c}\text { Mean } \\
\text { Velocity } \\
\left(m s^{-1}\right)\end{array}$ \\
\hline \multicolumn{6}{|l|}{ Riffles } \\
\hline \multicolumn{6}{|l|}{$\underline{\text { UHRRI reach }}$} \\
\hline Riffle 1 & 61 & 1,037 & 17 & $0.35 \pm 0.04$ & $0.90 \pm 0.05$ \\
\hline Riffle 2 & 32 & 416 & 13 & $0.52 \pm 0.05$ & $0.80 \pm 0.04$ \\
\hline Riffle 3 & 29 & 464 & 16 & $0.47 \pm 0.06$ & $0.89 \pm 0.04$ \\
\hline Riffle 4 & 55 & 935 & 17 & $0.55 \pm 0.06$ & $0.74 \pm 0.04$ \\
\hline Riffle 5 & 47 & 658 & 14 & $0.42 \pm 0.05$ & $0.92 \pm 0.04$ \\
\hline Riffle 6 & 32 & 448 & 14 & $0.39 \pm 0.04$ & $0.67 \pm 0.04$ \\
\hline \multicolumn{6}{|l|}{ Distant controls } \\
\hline Keys Riffle & 79 & 1,343 & 17 & $0.51 \pm 0.09$ & $0.77 \pm 0.04$ \\
\hline Olive Riffle & 96 & 1,344 & 14 & $0.49 \pm 0.05$ & $0.80 \pm 0.04$ \\
\hline \multicolumn{6}{|l|}{ Pools } \\
\hline \multicolumn{6}{|l|}{ UHRRI reach } \\
\hline$\overline{\text { Edinglassie }}$ & 827 & 17,005 & 21 & $1.31 \pm 0.03$ & $0.17 \pm 0.04$ \\
\hline Whites Winery & 1,268 & 32,591 & 25.9 & $1.50 \pm 0.05$ & $0.14 \pm 0.03$ \\
\hline Below Whites & 695 & 13,462 & 19 & $1.40 \pm 0.03$ & $0.17 \pm 0.04$ \\
\hline \multicolumn{6}{|l|}{ Distant controls } \\
\hline Olive Pool & 627 & 11,964 & 20 & $1.53 \pm 0.04$ & $0.14 \pm 0.03$ \\
\hline Racecourse & 1,198 & 29,595 & 25 & $1.44 \pm 0.05$ & $0.14 \pm 0.03$ \\
\hline
\end{tabular}

\section{Rehabilitation strategy/habitat manipulations}

Two types of SWH were introduced to riffles and pools to provide habitat for fishes. Bank embedded deflector jams (DFJs) were placed in riffles and pre-fabricated pool jams (PJs) were deployed in pools (Fig 2). The types of structure that could be manoeuvred into position and stabilised were largely dictated by logistical/cost constraints (Howell et al. 2005). The riffle DFJs were modelled on those successfully deployed in a similar study in the Williams River (Brooks et al. 2006). Two 22 tonne excavators and a 4WD tractor/loader were used to construct the multi-layered DFJs in riffles. The number of logs used to construct the DFJs ranged from 14 to 26, with the approximate volumes of the structures varying between 96 and $180 \mathrm{~m}^{3}$. Much of each structure was buried in the bank and stream bed to ensure stability and resistance to major flow events. The DFJs were installed in each of the treated riffles as pairs placed on alternating banks in an upstream and downstream configuration (Fig. 3). The main purpose of the upstream DFJ was to stabilise the bank and deflect flow toward the thalweg and downstream DFJ, while the main functional attributes of the downstream DFJ were to stabilise the bank and create scour to increase the diversity of habitat for fish. It was anticipated that flood flows, in conjunction with scour adjacent to the DFJs, would re-organise the substrate after construction, thus 
increasing the diversity of hydraulic habitats available for fishes. There was no permanent wood observed in any of the riffles prior to treatment with SWH. Following construction the treated riffles had wood loadings (volumes) of between 0.009 and $0.018 \mathrm{~m}^{3} \mathrm{~m}^{-2}$ within the low flow channel.

a)
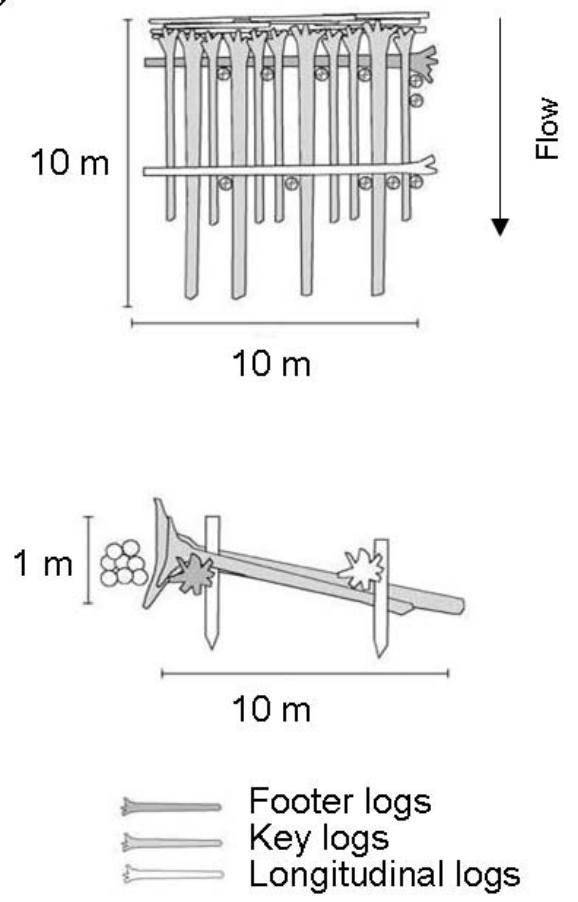

b)
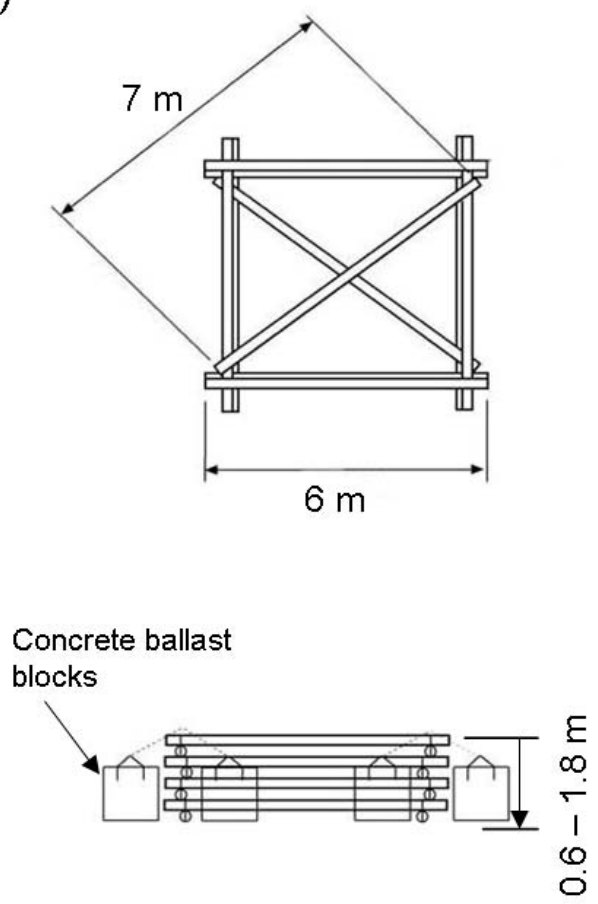

Figure 2. Typical design of a) riffle deflector jams (DFJs) and b) pool jams (PJs) showing plan and section layout. 


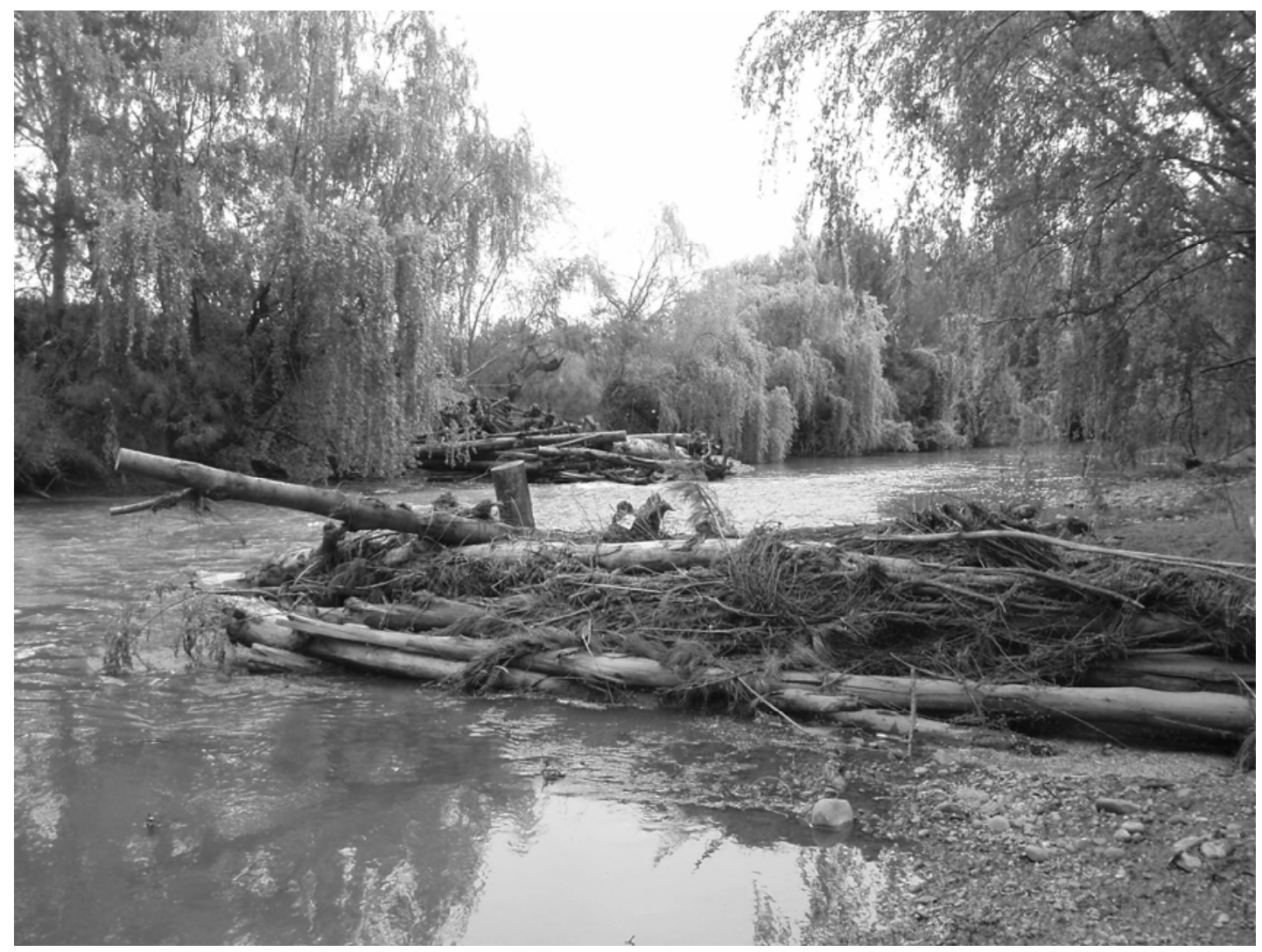

Figure 3. Photograph of the deflector jams in riffle 4 in October 2005, fifteen months after construction (photograph by T.D. Howell).

The pools selected within the UHRRI reach were deeply entrenched, and as a consequence, structures were pre-fabricated on the floodplain adjacent to their proposed in-stream locations before being lowered by crane into the channel as a single entity (Fig. 4). The pool jams (PJs) consisted of layers of logs (mean log length $601 \mathrm{~cm}$ ) bolted together with a cross brace at every second layer to provide additional strength. Each PJ was built to the height of the water depth at low flow at each of the installation locations, thus varying in height from 0.6 to $1.8 \mathrm{~m}$. Two hundred and thirty two logs were used to construct the 18 PJs with between 9 and 20 logs (2 to 7 layers) used for each structure. The structures varied in overall volume from 18.5 to $51.7 \mathrm{~m}^{3}$ and contained a wood volume of between 2.3 and $5.4 \mathrm{~m}^{3}$. To reduce flow drag the structures were installed with a corner facing upstream into the flow; this orientation also precluded the accumulation of additional wood on the structures by deflecting debris mobilised during high flow periods. Each structure was 'pinned' in place with 6 to 8 concrete ballast blocks weighing either 2.1 or 4.2 tonnes depending on the structure height. After installation each PJ was secured to the ballast blocks with galvanised anchor chain. Instalment of the PJs was completed in August 2004. Two randomly selected structures in each pool were infilled with smaller pieces of wood to increase the size diversity of interstitial spaces. The introduction of the PJs more than doubled the wood volume loading in each treated pool from 0.0007 $0.0013 \mathrm{~m}^{3} \mathrm{~m}^{-2}$ to $0.0016-0.0039 \mathrm{~m}^{3} \mathrm{~m}^{-2}$, while the loading in the control pools ranged between 0.0004 and $0.0007 \mathrm{~m}^{3} \mathrm{~m}^{-2}$. 


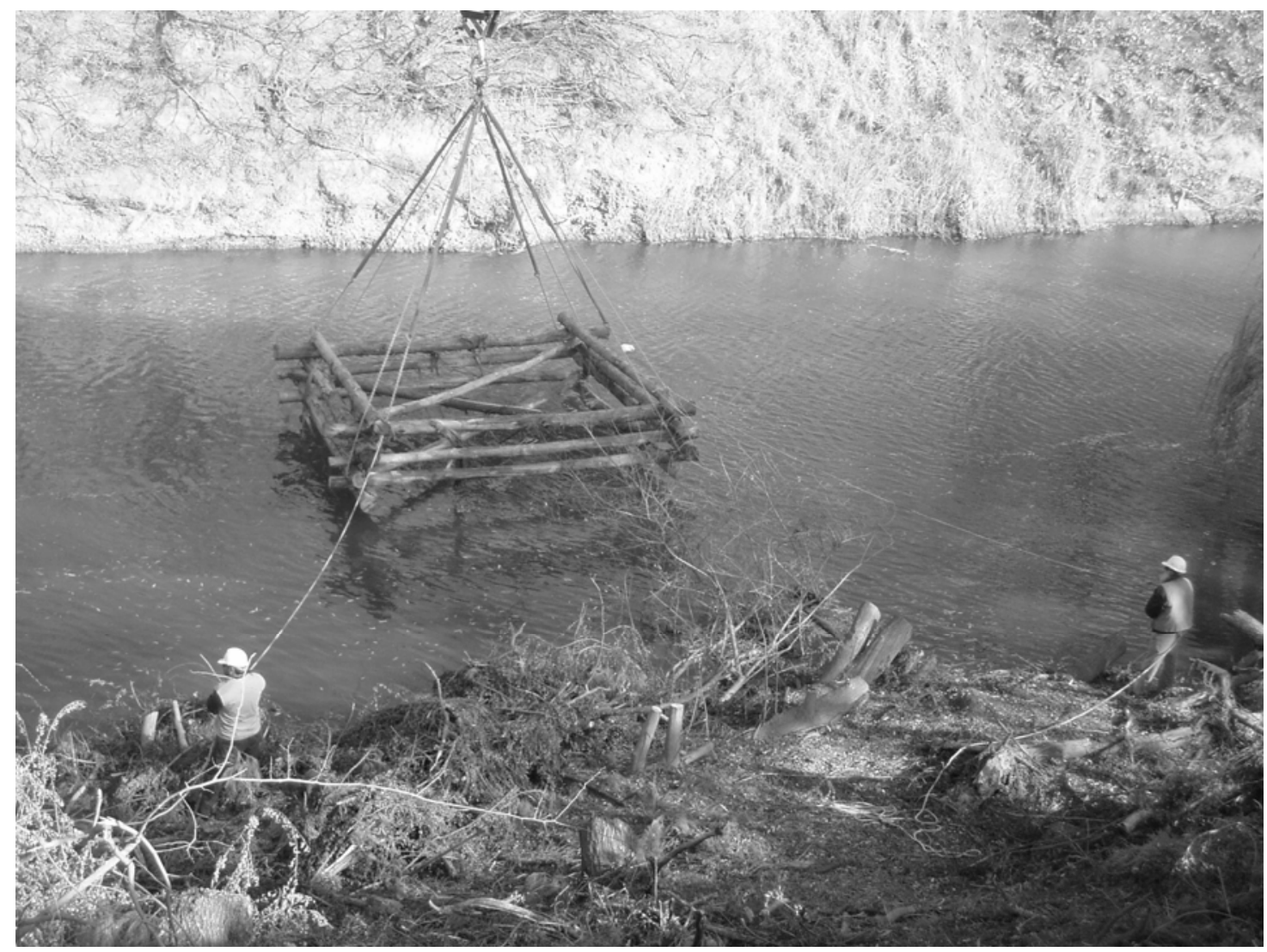

Figure 4. Pool Jam (PJ) being lowered by crane into Edinglassie Pool in June 2004 (photograph by T.D. Howell).

\section{Fish sampling techniques and regime}

The sampling regime was designed to examine the response of the total fish assemblage and individual species to differences in the types of habitat available for fishes in riffles (which lacked SWH prior to treatment) and pools (where the SWH doubled the existing wood load).

Riffles were sampled as effectively as the seasonal flow conditions allowed. On most occasions, sampling in each riffle consisted of four single-pass electrofishing operations - three backpack operations (one along each bank and one through the midchannel) and one boat operation (at the base of each riffle). However, during periods of low flow the boat electrofishing operation at the base of each study riffle was replaced by backpack electrofishing because these areas were too shallow to deploy the boat. Single pass backpack electrofishing thus covered approximately 90-300 metres of riffle habitat associated with stream banks and the mid-channel. The single operation at the base of each riffle was intended to capture any species associated with the deep water habitat parallel to the downstream DFJ. This habitat contributed between 3.5-7.1\% of the total riffle surface area. This sampling protocol was expected to capture all species present and to provide reliable estimates of relative abundance in each riffle. The elapsed time and the actual electrofisher 'power on' time were recorded upon completion of each electrofishing operation to measure sampling effort. Electrofisher 'power on' time is a more direct measure of sampling duration than elapsed time (Kennard et al. 2005) and was used in all conversions of fish data to catch-per-unit-effort (CPUE). 
The fish communities in the pools were sampled by boat electrofishing. Each electrofishing operation consisted of 60 seconds electrofishing 'power on' time, which was adequate to effectively sample the majority of fish associated with the introduced structural woody habitat (SWH), and in other areas of pools. Sampling in each pool consisted of 24 electrofishing operations throughout each pool and around SWH units. Electrofishing sites were selected within a stratified random sampling design in which left or right banks were selected randomly and a bank, mid-channel and opposite bank progression of electrofishing shots was followed in an upstream direction to increase the chance of retaining independent samples. The exact location of each electrofishing operation varied slightly between sampling periods due to changes in flow conditions and habitat complexity which influenced the most effective use of electrofishing time.

Fish observed to be affected by the electrofisher but not caught were also recorded where positive identification could be made. At the completion of each riffle and pool electrofishing operation, captured individuals were counted, identified to species level, measured for length (fork length for species with forked tails, total length for species with rounded tails) and returned to the water alive. Fish captured in riffles were released at least $20 \mathrm{~m}$ downstream from the collection site prior to subsequent electrofishing operations, while fish captured in pools were released $50 \mathrm{~m}$ below the next site subjected to electrofishing.

Biomass was estimated for each captured fish based on established length-weight relationships (Pusey et al. 2004; T. Howell, unpublished data). Biomass estimates were calculated for observed Anguilla sp. (eels) based on estimated lengths. For all other individuals observed but not caught and measured, biomass estimates were based on mean measured values for all fish caught in the reach on the same sampling occasion.

Quarterly sampling of fish assemblages was carried out from January 2004 to July 2004 before SWH introduction and from October 2004 to January 2006 after SWH introduction. It was considered that samples taken at quarterly intervals would be sufficiently spaced to minimise temporal dependence and any potential accumulative effects of capture and release sampling on fish assemblages.

\section{Statistical analysis}

Riffles and pools were analysed separately due to the differences in sampling techniques and effort. Abundance data for each species based on all individual electrofishing operations was pooled for each riffle or pool site by sampling occasion in preparation for multivariate comparisons of fish assemblage structure. Riffle data were pooled and standardised by electrofishing time to account for differences in riffle length and sampling effort. Bray-Curtis dissimilarity indices were calculated between all pairs of sites, employing the fourth-root transformation of abundance to accommodate the wide spread in values (Field et al. 1982; Clarke \& Warwick 2001). Non-metric multidimensional scaling (NMDS) based on Bray-Curtis dissimilarities was used to examine differences in fish assemblage composition between control and treatment sites before and after SWH introduction. Analysis of similarity (ANOSIM) was employed to detect differences between treatment levels within the before and after periods. The ANOSIM routine used a permutation/randomisation test comparing 
fish assemblages between treatment levels within a Bray-Curtis dissimilarity matrix (Clarke \& Warwick 2001). Differences between treatment levels, in terms of species abundances, were explored using similarity of percentages (SIMPER) (Clarke \& Warwick 2001) to determine the percentage contribution of individual species to average dissimilarity between treatment levels and times before and after SWH introduction. All multivariate analyses were performed using the Primer 5.0 statistical package (Clarke \& Warwick 2001).

Differences in species richness, abundance and biomass between the test and control riffles and test and control pools were analysed with the Multiple-Before-AfterControl-Impact (MBACI) model (Downes et al. 2002) using the SAS general linear model procedure (SAS 2003). The MBACI model is a three-factor ANOVA (testcontrol, before-after and sampling occasion) with repeated sampling and spatial replication. Locations nested within test-control (and subsequent interactions) were treated as random factors, while all other factors were considered fixed. Downes et al. (2002) consider the treatment $\mathrm{x}$ time period (before/after) interaction (CB) as an indication of the long-term impact of treatment, while treatment $\mathrm{x}$ sampling occasion (period before/after) (CT(B)) interaction as an indication of a short-term impact from which independent variables may recover relatively rapidly. For the MBACI analysis each riffle site was treated as a replicate, whereas for pools individual electrofishing operations were treated as replicates within sites. Fish sampling results for both riffles and pools were expressed as CPUE of the number of species, individuals and total biomass per 60 seconds electrofishing 'power on' time. Initial analysis of the relationship between variances and means for fish abundance and biomass data indicated heterogeneous variances so all abundance data were $\log (x+1)$ transformed prior to further analysis.

\section{Results}

\section{Description of fish assemblages}

A total of 9,700 fish ( $n=3,204$ in riffles, $n=6,496$ in pools) was recorded from all sites over the study period, representing 15 species from 10 families (Table 2). Three alien species were recorded during this study; C. carpio, Carassius auratus (goldfish) and Gambusia holbrooki (mosquito fish). All 15 fish species were recorded in pools, whereas Anguilla australis (short-finned eel), Nothesthes robusta (bullrout) and Philypnodon grandiceps (flathead gudgeon) were absent from riffles. The eight most abundant species across all sites, in descending order were: G. holbrooki, M. cephalus, Anguilla reinhardtii (long-finned eel), Gobiomorphus coxii (Cox's gudgeon), $R$. semoni, C. carpio, $M$. novemaculeata and Tandanus tandanus (eel-tailed catfish), accounting for $98.0 \%$ and $99.4 \%$ of all fish recorded in pools and riffles, respectively. Fish abundance in the riffle sites was dominated by A. reinhardtii, (41\%) G. coxii (22\%) and $R$. semoni (16\%), while the most abundant species in pools were G. holbrooki (38\%), M. cephalus (31\%), G. coxii (8\%) and C. carpio (7\%). The biomass of fish in the riffles was largely dominated by $A$. reinhardtii (51.5\%), $M$. cephalus (21.5\%), and C. carpio (18.5\%), while the majority of the pool biomass was contributed by two species, C. carpio (46.1\%) and M. cephalus (44.5\%). 
Table 2. Proportional abundance and biomass of each fish species based on total electrofishing time in Hunter River riffles (12 species) and pools (15 species) of the study reach (January 2004 - March 2006). * denotes alien fish species.

\begin{tabular}{|c|c|c|c|c|c|}
\hline Family and species & Common name & $\begin{array}{l}\text { \% of total } \\
\text { catch in riffles } \\
\text { (number of } \\
\text { individuals) }\end{array}$ & $\begin{array}{c}\% \text { of total } \\
\text { biomass in } \\
\text { riffles (total } \\
\text { weight in grams) }\end{array}$ & $\begin{array}{l}\text { \% of total } \\
\text { catch in pools } \\
\text { (number of } \\
\text { individuals) }\end{array}$ & $\begin{array}{c}\text { \% of total } \\
\text { biomass in } \\
\text { pools (total } \\
\text { weight in grams) }\end{array}$ \\
\hline \multicolumn{6}{|l|}{ Family Anguillidae } \\
\hline Anguilla australis Richardson, 1841 & Short-finned Eel & - & - & $0.02(1)$ & $0.007(185)$ \\
\hline Anguilla reinhardtii Steindachner, 1867 & Long-finned Eel & $41.2(1,319)$ & $51.5(85,992)$ & $3.6(236)$ & $4.1(111,078)$ \\
\hline \multicolumn{6}{|l|}{ Family Clupeidae } \\
\hline Potamalosa richmondia (Macleay, 1879) & Freshwater Herring & $0.5(15)$ & $0.3(426)$ & $1.0(62)$ & $0.3(8,142)$ \\
\hline \multicolumn{6}{|l|}{ Family Cyprinidae } \\
\hline * Carassius auratus Linnaeus, 1758 & Goldfish & $0.03(1)$ & $0.3(446)$ & $0.6(36)$ & $0.7(17,944)$ \\
\hline * Cyprinus carpio Linnaeus, 1758 & Common Carp & $1.0(31)$ & $18.5(30,888)$ & $7.7(497)$ & $46(1,259,544)$ \\
\hline \multicolumn{6}{|l|}{ Family Eleotridae } \\
\hline Gobiomorphus australis (Krefft, 1864) & Striped Gudgeon & $0.03(1)$ & $0.01(24)$ & $0.1(7)$ & $0.009(237)$ \\
\hline Gobiomorphus coxii (Krefft, 1864) & Cox's Gudgeon & $22.0(705)$ & $1.7(2,779)$ & $7.4(479)$ & $0.2(6,102)$ \\
\hline Hypseleotris compressa (Krefft, 1864) & Empire Gudgeon & $0.1(2)$ & $0.002(3)$ & $0.3(20)$ & $0.006(160)$ \\
\hline Philypnodon grandiceps (Krefft, 1864) & Flathead Gudgeon & - & - & $0.1(5)$ & $0.0005(15)$ \\
\hline \multicolumn{6}{|l|}{ Family Mugilidae } \\
\hline Mugil cephalus Linnaeus, 1758 & Sea Mullet & $7.2(231)$ & $21.5(35,861)$ & $39.8(1,937)$ & $44.5(1,216,486)$ \\
\hline \multicolumn{6}{|l|}{ Family Percichthyidae } \\
\hline Macquaria novemaculeata (Steindachner, 1866) & Australian Bass & $1.2(39)$ & $4.3(7,159)$ & $4.0(263)$ & $3.8(102,561)$ \\
\hline \multicolumn{6}{|l|}{ Family Plotosidae } \\
\hline Tandanus tandanus Mitchell, 1838 & Eel-tailed Catfish & $4.2(136)$ & $1.5(2,559)$ & $0.2(10)$ & $0.1(3,499)$ \\
\hline \multicolumn{6}{|l|}{ Family Poeciliidae } \\
\hline * Gambusia holbrooki Girard, 1859 & Mosquito Fish & $6.6(212)$ & $0.02(35)$ & $38.3(2,488)$ & $0.03(809)$ \\
\hline \multicolumn{6}{|l|}{ Family Retropinnidae } \\
\hline Retropinna semoni (Weber, 1895) & Australian Smelt & $16.0(512)$ & $0.3(522)$ & $7.0(452)$ & $0.04(1,103)$ \\
\hline \multicolumn{6}{|l|}{ Family Scorpaenidae } \\
\hline Notesthes robusta (Günther 1860) & Bullrout & - & - & $0.05(3)$ & $0.1(3,912)$ \\
\hline Totals & & 3,204 & 166,880 & 6,496 & $2,731,592$ \\
\hline
\end{tabular}




\section{Fish responses in riffles}

An ordination of fish assemblage composition (based on NMDS) illustrates substantial overlap in ordination space between treatment and control riffle sites before and after introduction of SWH (Fig. 5a). However, analysis of similarity (ANOSIM) detected significant differences in fish assemblage structure between treatment riffles after SWH addition and all other treatment and time comparisons (Global $R=0.102, p<0.01$ ). The addition of wood significantly altered fish assemblage structure in the treatment riffles in comparison to both close and distant control riffles $(p<0.05)$. A SIMPER analysis showed that higher abundances of $G$. holbrooki and $R$. semoni in the treated riffles following SWH introduction contributed $38-45 \%$ of these differences.
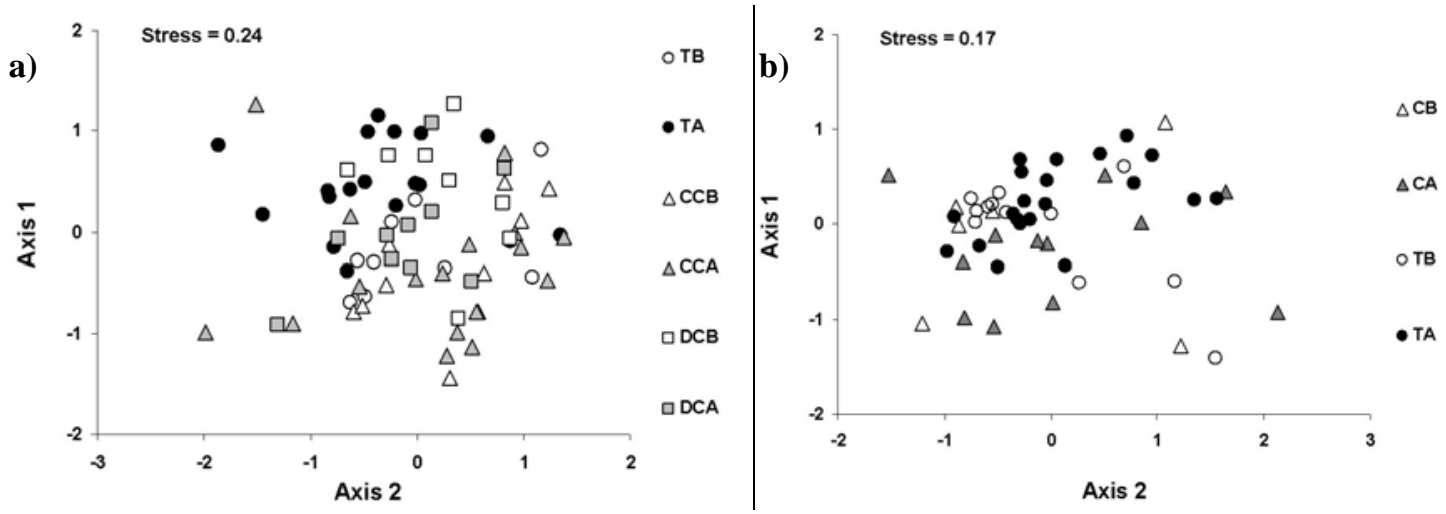

Figure 5. Non-metric multi-dimensional scaling ordination (NMDS) of fish assemblage structure across all seasonal sampling occasions before (January 2004 - July 2004) and after (October 2004 - January 2006) SWH introduction for (a) riffle sites and (b) pool sites in the Hunter River study reach. $T B=$ Treatment sites before, $T A=$ Treatment sites after, $C C B=C$ lose control sites, CCA=Close control sites after, DCB=Distant control sites before, DCA=Distant control sites after.

Standardised species richness (CPUE) recorded during riffle sampling ranged from 0.31 to 1.52 . Mean species richness increased marginally in all sites (controls and treatments) after SWH introduction, with the greatest increase observed in the riffles that received SWH (Fig. 6a). However, no significant differences in species richness were detected for any of the main effects or interactions (Table 3). 


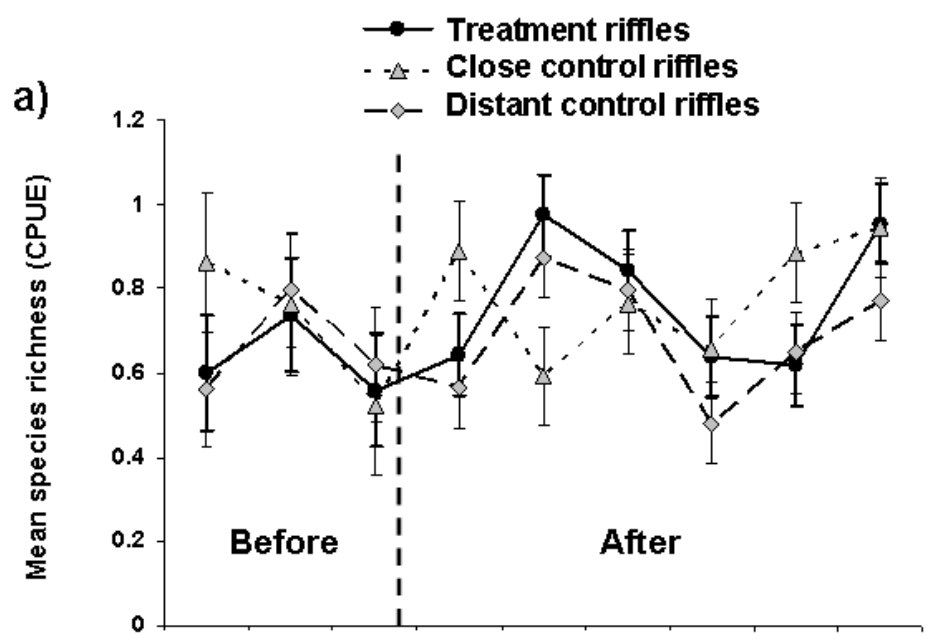

b)

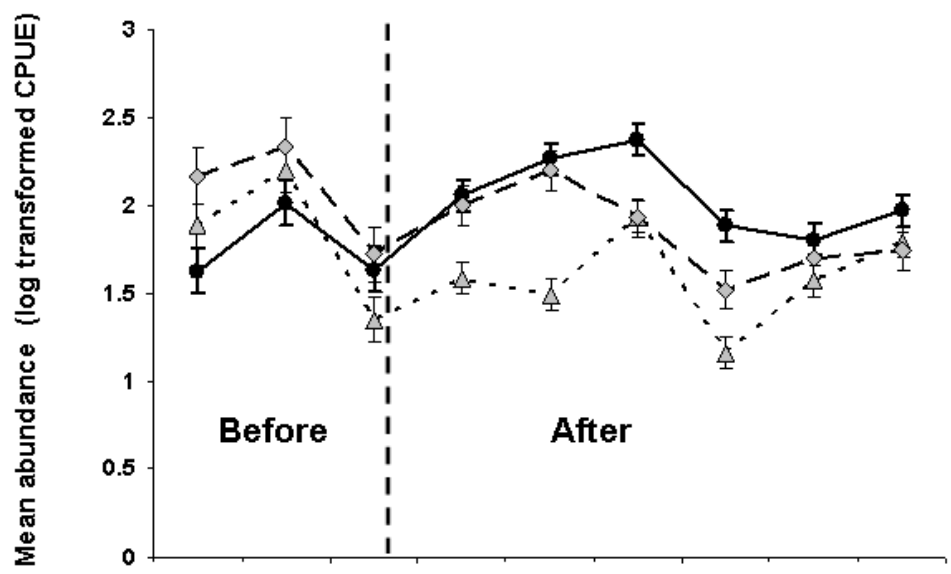

c)

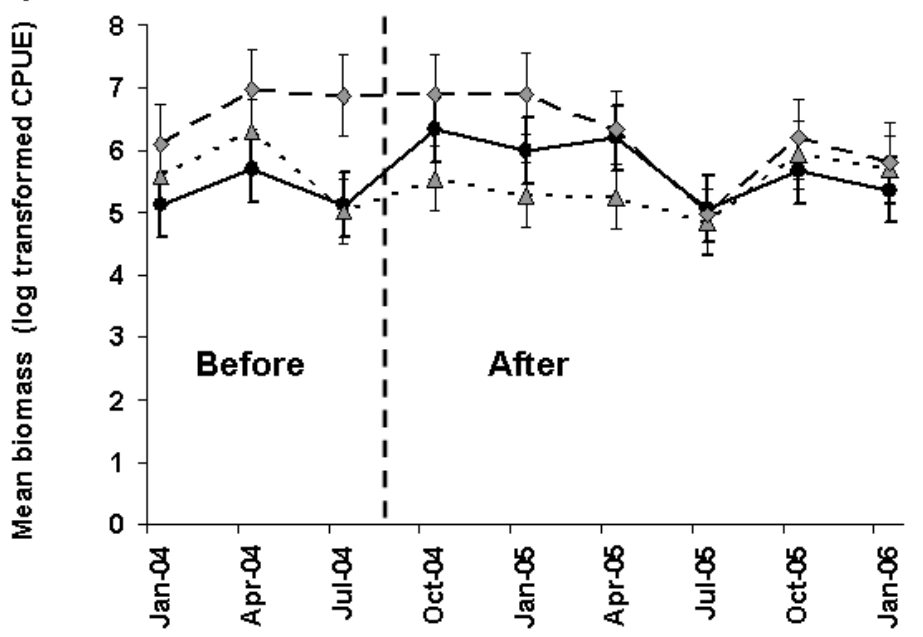

Sampling dates

Figure 6. (a) Mean species richness, (b) mean $\log (x+1)$ transformed fish abundance, and (c) mean $\log (x+1)$ transformed fish biomass (grams) CPUE (mean $\pm 95 \% \mathrm{CI}$ ) in riffles along the Hunter River study reach before (January 2004 to July 2004) and after SWH introduction (October 2004 - January 2006). 
Standardised fish abundance (CPUE) recorded during riffle sampling ranged from 0.69 to 12.61. A significant difference in fish abundance was detected between close and distant riffle sites across the study period (C) $\left(F_{2,5}=12.47, p<0.05\right)$ due to a higher abundance (mean $\pm \mathrm{CI})(1.96 \pm 0.12)$ in the distant controls than in the close controls $(1.70 \pm 0.10)(p<0.05)$ (Table 3$)$. Fish were significantly more abundant in autumn (April 2004 and 2005) compared to winter (July 2004 and 2005) $\left(F_{7,35}=4.52\right.$, $p<0.001$ ) (all $p<0.05$ ). An interaction between treatment $\mathrm{x}$ period (CB, Fig. 6b) was detected for $\log$ transformed fish abundance $\left(F_{2,5}=14.73, p<0.01\right)$. Tukey pairwise comparisons revealed that the close controls had lower fish abundance after SWH introduction $(1.59 \pm 0.09)$ than either the treatment riffles after $(2.06 \pm 0.09)(p$ $<0.01)$ or the distant controls before SWH introduction $(2.08 \pm 0.16)(p<0.05)$.

Standardised fish biomass (CPUE) recorded during riffle sampling ranged from 47.48 to 2005.77 grams. Temporal variation was observed across the study period $\left(F_{7,35}=\right.$ $3.2, p<0.05$ ), with log transformed fish biomass in riffles significantly lower in July 2005 (mean \pm CI) $(4.96 \pm 0.45)$ than in both April $(6.32 \pm 0.45)$ and October 2004 $(6.26 \pm 0.45)(p<0.05)$. An interaction between treatment $\mathrm{x}$ time period (CB) (Fig. $6 c)$ was detected for log transformed fish biomass $\left(F_{2,5}=13.62, p<0.05\right)$ (Table 3$)$. There was a higher biomass in the distant controls before SWH placement (mean \pm CI) $(6.65 \pm 0.24)$ than all other treatment and time comparisons except the distant controls after SWH addition $(6.18 \pm 0.17)(p<0.05)$. The biomass in the distant control riffles after SWH introduction was also significantly higher than the close control riffles after $(5.43 \pm 0.14)$ and the treatment riffles before SWH placement (5.31 \pm 0.52$)$ (both $p<0.05)$. 


\begin{tabular}{|c|c|c|c|c|c|c|}
\hline \multirow[b]{2}{*}{$\begin{array}{l}\text { Source of } \\
\text { variation }\end{array}$} & \multirow[b]{2}{*}{$d f$} & \multirow[b]{2}{*}{$\begin{array}{c}\text { MS } \\
\text { estimates }\end{array}$} & \multicolumn{2}{|c|}{ F-ratio } & \multirow[b]{2}{*}{ F-value } & \multirow[b]{2}{*}{$p$} \\
\hline & & & $\begin{array}{l}\text { Denominator } \\
\text { MS }\end{array}$ & $\begin{array}{c}\text { Denominator } \\
d f\end{array}$ & & \\
\hline \multicolumn{7}{|c|}{ Species Richness } \\
\hline \multicolumn{7}{|c|}{ (mean species richness CPUE $=0.73 \pm 0.03 \mathrm{SE}$ ) } \\
\hline \multicolumn{7}{|l|}{ Among locations } \\
\hline C & 2 & 0.040 & 0.145 & 5 & 0.27 & 0.772 \\
\hline $\mathrm{L}(\mathrm{C})$ & 5 & 0.145 & - & - & - & - \\
\hline \multicolumn{7}{|l|}{ Within locations } \\
\hline B & 1 & 0.128 & 0.040 & 5 & 3.18 & 0.135 \\
\hline $\mathrm{T}(\mathrm{B})$ & 7 & 0.083 & 1.598 & 35 & 1.81 & 0.116 \\
\hline $\mathrm{CB}$ & 2 & 0.017 & 0.040 & 5 & 0.43 & 0.671 \\
\hline $\mathrm{CT}(\mathrm{B})$ & 14 & 0.047 & 1.598 & 35 & 1.03 & 0.452 \\
\hline$L(C) B$ & 5 & 0.040 & 1.598 & 35 & 0.88 & 0.506 \\
\hline$L(C) T(B)$ & 35 & 1.598 & - & - & - & - \\
\hline \multicolumn{7}{|c|}{ Total Abundance (log transformed) } \\
\hline \multicolumn{7}{|c|}{ (mean abundance CPUE $=5.76 \pm 0.30 \mathrm{SE}$ ) } \\
\hline \multicolumn{7}{|l|}{ Among locations } \\
\hline C & 2 & 0.670 & 0.054 & 5 & 12.47 & 0.011 \\
\hline$L(C)$ & 5 & 0.054 & - & - & - & - \\
\hline \multicolumn{7}{|l|}{ Within locations } \\
\hline B & 1 & 0.011 & 0.035 & 5 & 0.32 & 0.594 \\
\hline $\mathrm{T}(\mathrm{B})$ & 7 & 0.452 & 0.100 & 35 & 4.52 & 0.001 \\
\hline $\mathrm{CB}$ & 2 & 0.519 & 0.035 & 5 & 14.73 & 0.008 \\
\hline $\mathrm{CT}(\mathrm{B})$ & 14 & 0.075 & 0.100 & 35 & 0.75 & 0.714 \\
\hline$L(C) B$ & 5 & 0.035 & 0.100 & 35 & 0.35 & 0.878 \\
\hline $\mathrm{L}(\mathrm{C}) \mathrm{T}(\mathrm{B})$ & 35 & 0.100 & - & - & - & - \\
\hline \multicolumn{7}{|c|}{$\begin{array}{l}\text { Biomass (log transformed) } \\
\text { (mean biomass CPUE }=437 \pm 46 \text { SE grams) }\end{array}$} \\
\hline \multicolumn{7}{|l|}{ Among locations } \\
\hline C & 2 & 4.198 & 1.591 & 5 & 2.64 & 0.165 \\
\hline $\mathrm{L}(\mathrm{C})$ & 5 & 1.591 & - & - & - & - \\
\hline \multicolumn{7}{|l|}{ Within locations } \\
\hline B & 1 & 0.009 & 0.086 & 5 & 0.1 & 0.759 \\
\hline $\mathrm{T}(\mathrm{B})$ & 7 & 1.428 & 0.447 & 35 & 3.2 & 0.010 \\
\hline $\mathrm{CB}$ & 2 & 1.178 & 0.086 & 5 & 13.62 & 0.010 \\
\hline $\mathrm{CT}(\mathrm{B})$ & 14 & 0.374 & 0.447 & 35 & 0.84 & 0.626 \\
\hline$L(C) B$ & 5 & 0.086 & 0.447 & 35 & 0.19 & 0.963 \\
\hline $\mathrm{L}(\mathrm{C}) \mathrm{T}(\mathrm{B})$ & 35 & 0.447 & - & - & - & - \\
\hline
\end{tabular}

Table 3. F-values and their associated significance levels (p) for linear mixed effects model ANOVA for total species richness, $\log (x+1)$ transformed abundance and $\log (x+1)$ transformed fish biomass in control and treatment riffles in the Hunter River. $\mathrm{C}$ - test-control, $\mathrm{L}$ - location, B - before-after, $\mathbf{T}$ - timing. Statistically significant results are shown in bold. 


\section{Fish responses in pools}

An NMDS ordination of fish assemblage composition before and after SWH introduction illustrates the substantial overlap between treatments and controls across all sampling occasions (Fig. 5b). No significant differences in fish assemblage structure were detected between control and treatment pools (ANOSIM Global $R=$ $0.08, p=0.076)$.

Mean species richness per electrofishing operation in pools ranged from 0.67 to 2.42. Species richness across all pool sites was higher before (mean $\pm \mathrm{CI})(1.71 \pm 0.09)$ than after SWH introduction $(1.52 \pm 0.08)\left(F_{1,3}=10.83, p<0.05\right.$, Table 4). Significant temporal variation in species richness was observed, with both controls and treatments following the same seasonal trends across sampling occasions $\left(F_{7,21}=\right.$ 13.72, $p<0.0001$, Fig 7a). Tukey pair-wise comparisons revealed that species richness in July $2005(0.84 \pm 0.14)$ was significantly lower than on all other occasions except July 2004 (all $p<0.01$ ). Similarly, species richness in July $2004(1.06 \pm 0.14)$ was lower than on all other sampling occasions except July 2005 and January 2006 $(1.39 \pm 0.14)$ (all $p<0.01)$. Species richness was typically highest during autumn and summer (April and January) sampling periods with the exception of January 2006, when richness was lower than in April 2004 and 2005 samples (1.98 \pm 0.14 and 1.98 \pm 0.14 respectively) and January $2004(1.39 \pm 0.14)$ (all $p<0.01)$.

Mean fish abundance per electrofishing operation in pools varied from 1.33 to 25.04. There was a significant difference in log transformed abundance between pool sites before (mean $\pm \mathrm{CI})(1.54 \pm 0.09)$ and after $(1.23 \pm 0.08) \mathrm{SWH}$ introduction $\left(F_{1,3}=\right.$ 26.36, $p<0.05$, Table 4$)$. The temporal variation between samples $\left(F_{7,21}=9.73, p<\right.$ $0.0001)$ was driven by a lower abundance in July $2005(0.72 \pm 0.16)$ than in January 2004 (1.86 \pm 0.16$)$, April $2004(1.71 \pm 0.16)$, October $2004(1.51 \pm 0.16)$ and January 2005 (1.38 \pm 0.16$)$ (all $p<0.05$, Fig 7b).

Mean fish biomass (CPUE) in pools varied from 260.28 to 4554.81 grams. There were no significant biomass differences between control and treatment pools, however a temporal trend in biomass was evident across all sites (Table 4). The temporal pattern was driven by significantly lower log transformed biomass values in July 2004 (mean \pm CI) (4.63 \pm 0.45), July 2005 (4.37 \pm 0.45) and January 2006 (4.11 \pm 0.45 ) than on all other sampling occasions (means 5.48 to 6.63$)(p<0.05$, Fig $7 c)$. 

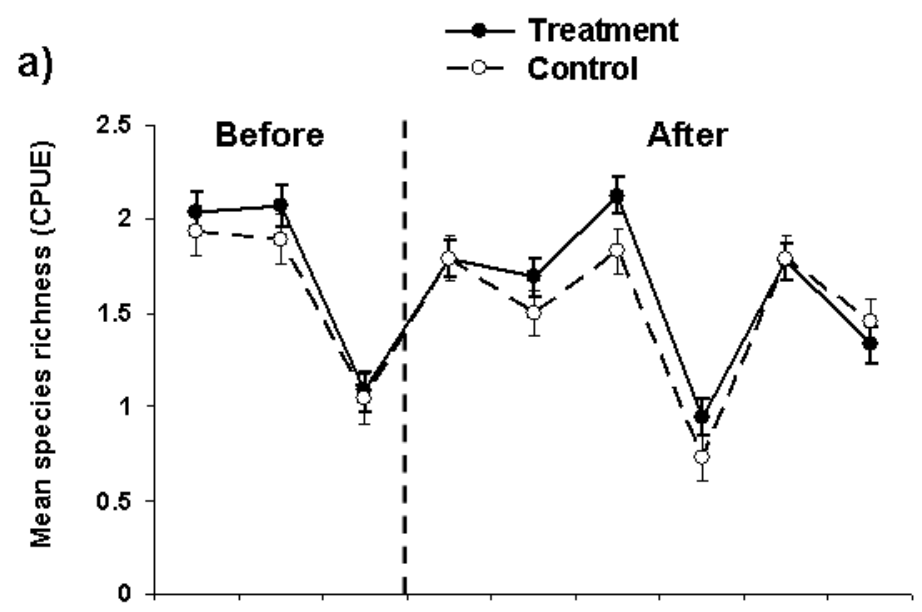

b)

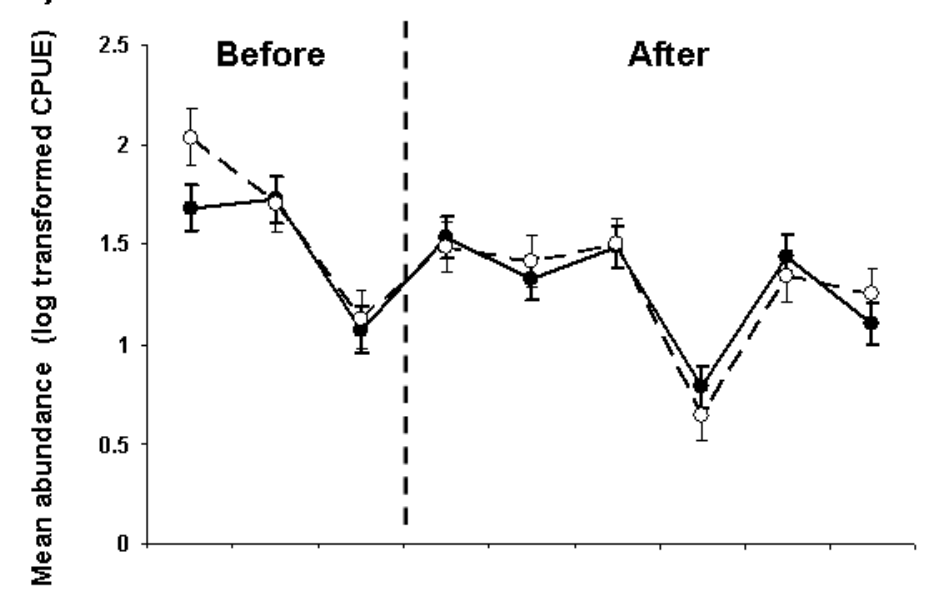

c)

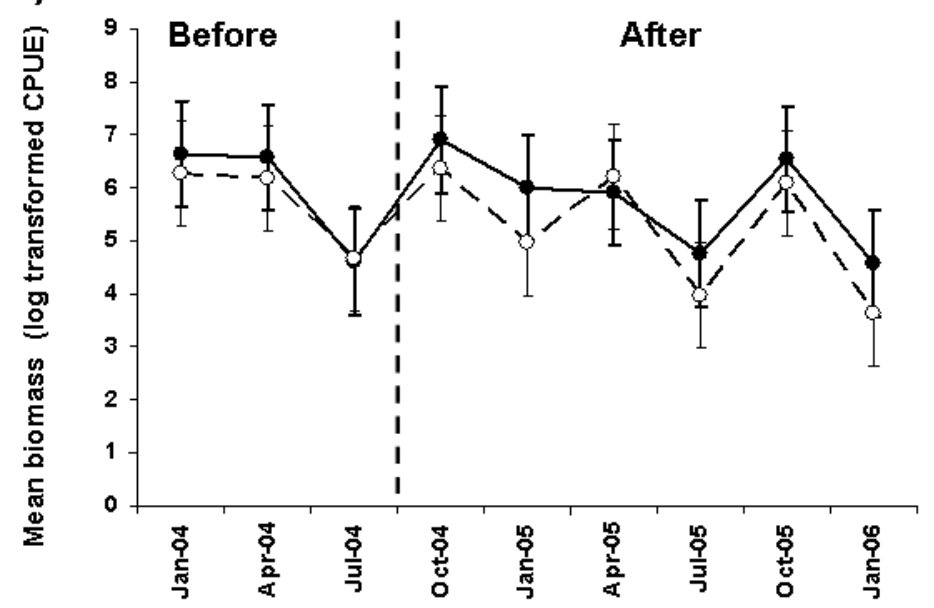

Sampling dates

Table 4. F-values and their associated significance levels (p) for linear mixed effects model analysis of ANOVA for species richness, $\log (x+1)$ transformed abundance and $\log (x+1)$ transformed fish biomass in control and treatment pools in the Hunter River. $\mathrm{C}-$ test- control, $\mathrm{L}$ - location, B - before-after, $\mathrm{T}$ - timing. Statistically significant results are shown in bold. 
Table 4. F-values and their associated significance levels (p) for linear mixed effects model analysis of ANOVA for species richness, $\log (x+1)$ transformed abundance and $\log (x+1)$ transformed fish biomass in control and treatment pools in the Hunter River. $\mathrm{C}-$ test- control, $\mathrm{L}$ - location, B - before-after, $\mathrm{T}$ - timing. Statistically significant results are shown in bold.

\begin{tabular}{|c|c|c|c|c|c|c|}
\hline \multirow[b]{2}{*}{$\begin{array}{l}\text { Source of } \\
\text { variation }\end{array}$} & \multirow[b]{2}{*}{$d f$} & \multirow[b]{2}{*}{ MS estimates } & \multicolumn{2}{|c|}{ F-ratio } & \multirow[b]{2}{*}{ F-value } & \multirow[b]{2}{*}{$p$} \\
\hline & & & $\begin{array}{c}\text { Denominator } \\
M S\end{array}$ & $\begin{array}{c}\text { Denominator } \\
d f\end{array}$ & & \\
\hline \multicolumn{7}{|c|}{$\begin{array}{l}\text { Species Richness } \\
\text { (mean species richness CPUE }=5.68 \pm 0.28 \text { SE) }\end{array}$} \\
\hline \multicolumn{7}{|l|}{ Among locations } \\
\hline C & 1 & 2.489 & 2.866 & 3 & 0.87 & 0.420 \\
\hline $\mathrm{L}(\mathrm{C})$ & 3 & 2.866 & - & - & - & - \\
\hline \multicolumn{7}{|l|}{ Within locations } \\
\hline B & 1 & 9.086 & 0.839 & 3 & 10.83 & 0.046 \\
\hline $\mathrm{T}(\mathrm{B})$ & 7 & 23.345 & 1.701 & 21 & 13.72 & $<0.0001$ \\
\hline $\mathrm{CB}$ & 1 & 0.068 & 0.839 & 3 & 0.08 & 0.794 \\
\hline $\mathrm{CT}(\mathrm{B})$ & 7 & 0.572 & 1.701 & 21 & 0.34 & 0.928 \\
\hline$L(C) B$ & 3 & 0.839 & 1.701 & 21 & 0.49 & 0.691 \\
\hline$L(C) T(B)$ & 21 & 1.701 & - & - & - & - \\
\hline \multicolumn{7}{|c|}{$\begin{array}{l}\text { Abundance }(\log \text { transformed) } \\
\text { (mean abundance CPUE }=3.06 \pm 0.10 \mathrm{SE} \text { ) }\end{array}$} \\
\hline \multicolumn{7}{|l|}{ Among locations } \\
\hline$C$ & 1 & 0.380 & 2.822 & 3 & 3.36 & 0.739 \\
\hline $\mathrm{L}(\mathrm{C})$ & 3 & 2.822 & - & - & - & - \\
\hline \multicolumn{7}{|l|}{ Within locations } \\
\hline B & 1 & 25.372 & 0.963 & 3 & 26.36 & 0.014 \\
\hline $\mathrm{T}(\mathrm{B})$ & 7 & 11.675 & 1.200 & 21 & 9.73 & $<0.0001$ \\
\hline $\mathrm{CB}$ & 1 & 0.419 & 0.963 & 3 & 0.44 & 0.556 \\
\hline $\mathrm{CT}(\mathrm{B})$ & 7 & 0.676 & 1.200 & 21 & 0.56 & 0.777 \\
\hline$L(C) B$ & 3 & 0.963 & 1.200 & 21 & 0.8 & 0.506 \\
\hline$L(C) T(B)$ & 21 & 1.200 & - & - & - & - \\
\hline \multicolumn{7}{|c|}{$\begin{array}{l}\text { Biomass (log transformed) } \\
\text { (mean biomass CPUE }=2,018 \pm 96 \text { SE grams) }\end{array}$} \\
\hline \multicolumn{7}{|l|}{ Among locations } \\
\hline $\mathrm{C}$ & 1 & 54.813 & 12.677 & 3 & 4.320 & 0.129 \\
\hline $\mathrm{L}(\mathrm{C})$ & 3 & 12.677 & - & - & - & - \\
\hline \multicolumn{7}{|l|}{ Within locations } \\
\hline B & 1 & 20.508 & 8.063 & 3 & 2.54 & 0.209 \\
\hline $\mathrm{T}(\mathrm{B})$ & 7 & 127.808 & 14.644 & 21 & 8.73 & $<0.0001$ \\
\hline CB & 1 & 7.128 & 8.063 & 3 & 0.88 & 0.417 \\
\hline $\mathrm{CT}(\mathrm{B})$ & 7 & 5.624 & 14.644 & 21 & 0.38 & 0.901 \\
\hline$L(C) B$ & 3 & 8.063 & 14.644 & 21 & 0.55 & 0.653 \\
\hline$L(C) T(B)$ & 21 & 14.644 & - & - & - & - \\
\hline
\end{tabular}




\section{Discussion}

Fish assemblage composition in the study sites was typical of that found within the 50-200 m altitude zone in the Hunter River and adjacent catchments (Harris \& Gerhke 1997; Howell \& Creese in press). With the exception of Potamalosa richmondia (freshwater herring), all native species recorded in the study reach are widespread and relatively common. It is presently uncertain whether one native species (T. tandanus) occurs naturally in the Hunter catchment or has been translocated (D. Jerry pers comm.; Pusey et al. 2004). Species richness was higher in pools (12 native and 3 alien species), with all species recorded in riffles also recorded in pools. The three species recorded exclusively from pools (A. australis, $N$. robusta and $P$. grandiceps) represented only $0.09 \%$ of total fish abundance, consequently, the riffle and pool fish faunas were essentially the same with respect to species composition.

Species richness was comparable between all control and treatment riffles across the entire study period, however, the addition of SWH significantly altered fish assemblage structure and fish abundance. Higher abundances of $G$. holbrooki and $R$. semoni in the treated riffles following SWH introduction dominated these differences. The increased abundance of G. holbrooki in riffles treated with SWH highlights the potential for habitat enhancement to benefit alien species, in this case one that is known to cause a range of ecological problems for small-bodied native fishes in Australia (Arthington \& Lloyd 1989; Howe et al. 1997; Ivanstoff \& Aarn 1999). In the Hunter River there could be potential for $G$. holbrooki to adversely affect $R$. semoni since both species were captured at the riffle sites treated with SWH. However, these species used different types of hydraulic habitat created by the riffle deflector jams; $G$. holbrooki occupied small areas of slack water behind the deflector jams, whereas $R$. semoni were caught in flowing water immediately adjacent to the $\mathrm{SWH}$. The occupation of different habitats may reduce the potential for aggressive or trophic interactions between these alien and native species (Arthington et al. 1983; Arthington \& Marshall 1999). Over the study period G. holbrooki, although abundant in pools, was not captured from the pool $\mathrm{SWH}$, and while C. carpio was caught from pool SWH this species appeared to prefer the pre-existing habitat provided by the vegetation overhang associated with Salix spp. (willow trees) (Howell 2008). These observations highlight the need for careful consideration of the types and placement of engineered $\mathrm{SWH}$ in pool-riffle sequences relative to pre-existing habitat structure and the known habitat preferences of alien and native species.

With the exception of significant increases in abundance of $G$. holbrooki and $R$. semoni; fish responses to the introduction of SWH in riffles were less pronounced than anticipated, with little change in abundance and biomass for most species. This may have been due in part to the failure of the SWH to induce substantial change in habitat diversity in treatment sites. Based on the results from a similar study undertaken in the Williams River (Brooks et al. 2006) it was anticipated that the riffle deflector jams would induce gravel mobilization during high flow events, thus increasing the morphological and hydraulic habitat diversity within riffles. In the Williams River study there were substantial site specific increases in both fish species diversity and abundance following the construction of deflector jams at the base of riffles (Brooks et al. 2006). However, during the Hunter River study there were no flow events large enough to mobilize and re-organize riffle substrates. This was largely a consequence of the prevailing drought rather than an effect of flow 
regulation by Glenbawn Dam. The minimal change to the morphology of the treatment riffles that did occur following SWH introduction was the creation of small areas of slack water behind the deflector jams immediately after they were put in place, rather than marked re-organisation of stream substrates and increasing hydraulic habitat diversity over time (Howell 2008).

Fish responses to SWH in pools were less pronounced than those recorded for riffle DFJs. Multivariate comparisons of fish assemblages detected no differences in fish assemblage structure that could be attributed to the introduction of SWH. Similarly, the MBACI analysis did not detect any increase in species richness, abundance or biomass in the treatment pools relative to the control pools over the study period. However, there was a strong seasonal signal observed over the study period for all univariate measures of fish response in pools. Fish species richness, abundance and biomass in pools were lowest during winter (July 2004 and 2005) and typically highest in autumn (April 2004 and 2005). Harris and Gehrke (1997) observed similarly low capture rates during winter in rivers across New South Wales. This may have been due to lower mobility of fish, and hence their catchability, in the lower water temperatures.

One explanation for the lack of response to SWH in pools is that the volume of wood introduced may have been insufficient to elicit a measurable response from the fish assemblage at the scale of the entire pool. Even though SWH introduction more than doubled the wood loadings of the treatment pools (wood volume loadings were $0.0007-0.0013 \mathrm{~m}^{3} \mathrm{~m}^{-2}$ before SWH introduction and $0.0016-0.0038 \mathrm{~m}^{3} \mathrm{~m}^{-2}$ afterwards) they were still only approximately $10 \%$ of those typically reported for undisturbed streams in south-eastern Australia (0.011 - $0.044 \mathrm{~m}^{3} \mathrm{~m}^{-2}$, Marsh et al. 1999). This has strong implications for future river rehabilitation using SWH, considering the high costs of the structures introduced into the Hunter study area (> $\$ 100,000$ for 18 structures in three pools). Further experimentation will be required to assess the percentage of 'natural' wood loads necessary to elicit a measurable response from native fishes at the pool scale in the Hunter River.

Another plausible explanation for the relatively weak fish response to $\mathrm{SWH}$ in riffles and the overall lack of response in the pools may be the influence of processes occurring over spatial scales greater than the UHRRI reach. A growing body of literature suggests that multiple large scale disturbances may limit the capacity of river fishes to respond to rehabilitation of a relatively small area of habitat (Fausch et al. 2002; Bond \& Lake 2003; McClurg et al. 2007). Most fish species collected during this study use habitats that extend over spatial scales far greater than that of the study reach (Pusey et al. 2004). Consequently, local rehabilitation efforts may simply result in a reshuffling of individuals at the local scale, and fail to produce notable changes in fish diversity, assemblage structure, and productivity at broader scales in highly degraded catchments (Pretty et al. 2003; Lepori et al. 2005). Successful restoration in degraded systems may require multiple, integrated restoration actions that address factors limiting fish diversity and productivity at the catchment scale.

This study highlights the potential for logistical issues to constrain effective experimental design (Howell et al. 2005), specifically: the availability of suitable treatment sites, lack of totally independent spatial controls, and relatively short prerestoration and post-restoration sampling periods. The sites available for treatment 
were restricted (by agency participants and funding constraints) to the UHRRI reach and, as such, all of the study sites could be somewhat spatially confounded. It was not possible to place reference sites on a separate, comparable, undisturbed river, as no such sites existed. The fish abundance response recorded for treatment riffles relative to close controls suggests that the data may have been spatially autocorrelated. The SIMPER results identified that the increase in fish abundance at the treatment riffles was due to an increase in G. holbrooki and $R$. semoni and a concurrent decrease in both these species in the close control riffles. These fish may simply have moved from close controls to treatment sites (distances of 55 to 510 meters were involved). However, the distant controls were more likely to be spatially independent of treatment riffles, and their inclusion in the study design allows greater confidence in our conclusion that $G$. holbrooki and $R$. semoni increased in abundance in the treated riffles compared to controls following SWH introduction.

Longer pre- and post- treatment periods would provide both a more robust background against which changes in fish assemblages could be assessed, and a better understanding of long-term ecological outcomes from habitat restoration. A longer period of monitoring could be important given the strong temporal patterns observed. The overall study period was dictated by the timing of the SWH introduction which was constrained by several factors typical of many rehabilitation studies, in that funding and stakeholder contributions and expectations dictated the timing of rehabilitation works and the duration of the pre- and post-treatment evaluation periods, in this case two years. Finally, in the Hunter study area, fish responses to SWH in riffles may have been inhibited by the effects of drought and river regulation on river flows. An extended monitoring period incorporating high flow events that mobilize gravel may be necessary to detect the full effects of SWH on the morphology and hydraulic habitat diversity of riffles, and hence effects on fish assemblages at the riffle scale.

\section{Implications for practice}

- The Multiple-Before-After-Control-Impact experimental design and analysis offers a powerful tool for testing fish responses to river rehabilitation works such as the introduction of Structural Woody Habitat.

- In the Hunter River bank embedded deflector jams appear to have greater potential to increase hydraulic habitat diversity in riffles and to have more effect on fish assemblages than the large timber pool jams.

- Local scale rehabilitation efforts may need to be embedded within multi-factor integrated restoration strategies that address stressors limiting fish assemblages and fish productivity at the catchment scale. 


\section{Acknowledgements}

The authors would like to thank the staff at New South Wales Department of Primary Industries (NSW Fisheries); Simon Hartley, Tony Fowler, Keryn Reeves, Natalie Reed, Andrew Bruce, Michael Rodgers, Hoa Tran, Michael Howell, Rod Gleeson, Jason Kelly, Nick Alexeyeff, Kirstie Webb and Roger Laird. We gratefully acknowledge the assistance of Barbara Downes and Sam Lake for guidance in experimental design and data analyses. Many thanks to all the UHRRI team, in particular Sarah Mika and Dan Keating for their support, advice and constructive comments, and John Spencer for help with computer applications and figures. Sincere thanks to the UHRRI sponsors and local landowners for their support and unlimited access to the Hunter River study sites. This work was funded by an Australian Research Council Linkage Grant (LP0346918) with support from the following industry partners: Macquarie Generation, Bengalla Mine, Mt Arthur Coal, Department of Natural Resources, Department of Lands, and Hunter and Central Rivers Catchment Management Authority. We thank Nick Bond and an anonymous reviewer for insightful comments on the thesis of which this paper forms a part. Comments from two anonymous reviewers greatly improved the final version of this manuscript. This research was completed with support and funding from the Australian Rivers Institute, Griffith University. 


\section{References}

Arthington A. H., and C. J. Marshall. 1999. Diet of the exotic mosquitofish, Gambusia holbrooki, in an Australian lake and potential for competition with indigenous fish species. Asian Fisheries Science 12:1-8.

Arthington A.H., D. A. Milton, and R. J. McKay. 1983. Effects of urban development and habitat alterations on the distribution and abundance of native and exotic freshwater fish in the Brisbane region, Queensland. Australian Journal of Ecology 8:87-101.

Arthington, A. H., and L. N. Lloyd 1989. Introduced Poeciliidae in Australia and New Zealand. Pages 333-348 in G. K. Meffe and F. F. Snelson, editors. Ecology and Evolution of Livebearing Fishes (Poeciliidae), Prentice-Hall, New York, United States of America.

Bernhardt, E. S., M. A. Palmer, J. D. Allan, G. Alexander, K. Barnas, S. Brooks, J. Carr, S. Clayton, C. Dahm, J. Follstad-Stah, D. Galat, S. Gloss, P. Goodwin, J. L. Meyer, T. K. O’Donnell, L. Pagano, B. Powell, and E. Sudduth. 2005. Synthesizing U.S. river restoration efforts. Science 308:636-637.

Bond, N. R., and P. S. Lake. 2003. Local habitat restoration in streams: Constraints on the effectiveness of restoration for stream biota. Ecological Management and Restoration 4:193-198.

Brierley, G., C. Miller, K. Fryirs, A. J. Boulton, D. S. Ryder, M. Leishman, D. Keating, and J. Lander. 2005. Making integrative, cross-disciplinary research happen: Initial lessons from the Upper Hunter River Rehabilitation Initiative. Pages 125-133 in I. D. Rutherford, I. Wiszniewski, M. AskeyDoran, and R. Glazik, editors. Linking Rivers to Landscapes. Department of Primary Industries, Water and Environment, Hobart, Tasmania.

Brooks, A. P., and T. Cohen 2005. Wood reintroduction in a multi-objective river rehabilitation project: the Upper Hunter River Rehabilitation Initiative. Pages 134-141 in I. D. Rutherford, I. Wiszniewski, M. Askey-Doran, and R. Glazik, editors. Linking Rivers to Landscapes. Department of Primary Industries, Water and Environment, Hobart, Tasmania.

Brooks, A. P., T. Howell, T. B. Abbe, and A. H. Arthington. 2006. Confronting hysteresis: Wood based river rehabilitation in highly altered riverine landscapes of south-eastern Australia. Geomorphology 79: 395-422.

Chapman, M. G. 1999. Improving sampling designs for measuring restoration in aquatic habitats. Journal of Aquatic Ecosystem Stress and Recovery 6:235261.

Clarke, K. R., and R. M. Warwick. 2001. Change in Marine Communities: An Approach to Statistical Analysis and Interpretation, 2nd edition. Plymouth Marine Laboratory, Plymouth, Massachusetts.

Downes, B. J., L. A. Barmuta, P.G. Fairweather, D. P. Faith, M. J. Keough, P. S. Lake, B. D. Mapstone, and G. P. Quinn. 2002. Monitoring ecological impacts: Concepts and practice in flowing waters. Cambridge University Press, Cambridge, United Kingdom.

Fausch K. D., C. E. Torgensen, C. V. Baxter, H. W. Li. 2002. Landscapes to riverscapes: bridging the gap between research and conservation of stream fishes. BioScience 52:483-498.

Field, J. G., K. R. Clarke, and R. M. Warwick. 1982. A practical strategy for analyzing multispecies distribution patterns. Marine Ecology Progress Series 8:37-52. 
Harris, J. H., and P. C. Gehrke. 1997. Fish and rivers in stress: the NSW Rivers Survey. NSW Fisheries Office of Conservation and Cooperative Research Centre for Freshwater Ecology, Sydney, New South Wales (available from: http://freshwater.canberra.edu.au/Publications.nsf/0/b91721ae5974c0e9ca25 6f19000f0620?OpenDocument).

Howe, E., C. Howe, R. Lim, and M. Burchett. 1997. Impact of the introduced poeciliid Gambusia holbrooki (Girard, 1859) on the growth and reproduction of Pseudomugil signifer (Kner, 1865) in Australia. Marine and Freshwater Research 48:425-434.

Howell, T., A. A. Arthington, B. Pusey, A. P. Brooks, R Creese, and B Downes. 2005. Measuring the effect of river rehabilitation for fish: logistical constraints on experimental design. Pages 299 - 305 in I. D. Rutherford, I. Wiszniewski, M. Askey-Doran, and R. Glazik, editors. Linking Rivers to Landscapes. Department of Primary Industries, Water and Environment, Hobart, Tasmania.

Howell, T. D. 2008. Fish responses to the introduction of Structural Woody Habitat in two coastal rivers in New South Wales, Australia. Ph D dissertation. Griffith University, Brisbane, Australia.

Howell, T., and R. Creese in press. Freshwater fish communities of the Hunter, Manning, Karuah and Macquarie-Tuggerah catchments: status and trends. Department of Primary Industries, Nelson Bay, New South Wales.

Ivantsoff, W., and Aarn. 1999. Detection of predation on Australian native fishes by Gambusia holbrooki. Marine and Freshwater Research 50:467-468.

Kennard, M. J., A. H. Arthington, B. J. Pusey., and B. D. Harch. 2005. Are alien fish a reliable indicator of river health? Freshwater Biology 50:174-193

Lake, P. S. 2001. On the maturing of restoration: linking ecological research and restoration. Ecological Management and Restoration 2:110-115.

Lepori, F., D. Palm, E. Brannas, and B. Malmqvist. 2005. Does restoration of structural heterogeneity in streams enhance fish and macroinvertebrate diversity? Ecological Applications 15:2060-2071.

Marsh, N., K. Jerie, and C. Gippel. 1999. Sampling large woody debris loading in streams: a comparison of the line-intersect and census methods. Pages 433437 in I. Rutherford and R. Bartley, editors. Proceedings of the Second Australian Stream Management Conference, Adelaide, South Australia.

McClurg, S., J. T. Petty, J. Clayton, and P. Mazik. 2007. Stream ecosystem response to limestone treatment in acid impacted watersheds of the Allegheny Plateau ecoregion. Ecological Applications 17:1087-1104.

Michener, W. K. 1997. Quantitatively evaluating restoration experiments: Research designs, statistical analysis, and data management consideration. Restoration Ecology 5:324-337.

Minns, C. K., J. R. M. Kelso, and R. G. Randall. 1996. Detecting the response of fish to habitat alterations in freshwater ecosystems. Canadian Journal of Fisheries and Aquatic Sciences 53:403-414.

Palmer, M. A., E. S. Bernhardt, J. D. Allan, P. S. Lake, G. Alexander, S. Brooks, J. Carr, S. Clayton, C. N. Dahm, J. Follstad Shah, D. L. Galat, S. G. Loss, P. Goodwin, D. D. Hart, B. Hassett, R. Jenkinson, G. M. Kondolf, R. Lave, J. L. Meyer, T. K. O’Donnell, L. Pagano, and E. Sudduth. 2005. Standards for ecologically successful river restoration. Journal of Applied Ecology 42:208217. 
Palmer, M. A., and Filoso, S. 2009. Restoration of ecosystem services for environmental markets. Science 325: 575-576.

Pretty, J. L., S. S. C. Harrison, D. J. Shepherd, C. Smith, A. G. Hildrew, and R. D. Hey. 2003. River rehabilitation and fish populations: assessing the benefit of instream structures. Journal of Applied Ecology 40:251-265.

Pusey, B. J., M. J. Kennard, and A. H. Arthington. 2004. Freshwater fishes of northeastern Australia. CSIRO Publishing, Collingwood, Victoria.

Race, M. S. 1985. Critique of present wetlands mitigation policies in the United States based on an analysis of past restoration projects in San Francisco Bay. Environmental Management 9:71-82.

Roni, P., M.C. Lierman, G. Jordan, and E.A. Steel. 2005. Steps for designing a monitoring and evaluation program for aquatic restoration. Pages 13-34 in: Roni, P., Quimby, E. editors. Monitoring stream and watershed restoration. American Fisheries Society, Bethesda, Maryland, U.S.A.

SAS (C) 2003. Version 9.1.3. SAS Institute Incorporated, Cary, North Carolina, USA.

Smokorowski, K. E., K. J. Whithers, and J. R. M. Kelso. 1998. Does habitat creation contribute to management goals? An evaluation of literature documenting freshwater habitat rehabilitation or enhancement projects. Canadian Technical Report of Fisheries and Aquatic Sciences No. 2249.

Spencer, J., K. Fryirs, D. Keating, and G. Brierley. 2004. River Styles in the Upper Hunter Catchment. Report presented to the Upper Hunter River Rehabilitation Initiative. Macquarie University, Sydney. 